\section{SHOWBIZ NEWS}

\section{Richard Who?}

Evolutionary biologist Richard Dawkins is to follow in the acting footsteps of Derek Jacobi and Kylie Minogue - not to mention his wife, Lalla Ward - by making a guest appearance on the legendary British sci-fi series Doctor Who. His late friend Douglas Adams, a Who script editor, would have been delighted.

\section{SCORECARD}

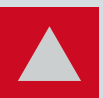

Brazilian contraception The government aims to safeguard the Amazon

by marketing condoms made from sustainably harvested rubber trees in the forest.

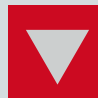

US health information A US governmentfunded health-

information search engine called Popline last week blocked all hits relating to the search term 'abortion', only reinstating them after a public outcry.

\section{ON THE RECORD}

\section{c'It was a big bit of gear and it got pretty warm.”}

Hafsteinn Jonsson, one of the Swedish team that helped to create the world's first ever 40-gigabit-persecond Internet connection, explains why its recipient, the mother of a colleague, used it to dry her laundry.

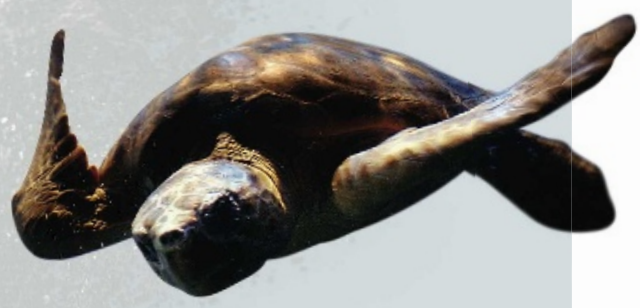

\section{ZOO NEWS}

\section{Strong bond}

A loggerhead turtle, badly injured when it washed up on a British beach, has been saved ... by a dentist. The turtle, nicknamed James Bond after his official stranding number (007), damaged his shell on rocks thousands of kilometres from his warmer home waters, and was patched up using a compound more commonly used to protect delicate dental work.

Sources: The Independent, BBC, Wired blogs, The Local, The Times

\title{
Gertrude versus Goliath
}

An octogenarian physicist is taking on the world's largest electronics companies, which, she claims, have infringed her patent for making blue and ultraviolet light-emitting diodes (LEDs) and short-wavelength laser diodes.

On 20 March, the International Trade Commission, which oversees imports to the United States, announced it would investigate a complaint filed by Gertrude Neumark Rothschild, a professor emeritus at Columbia University in New York City. The complaint names some 30 companies, including Sony, Toshiba and Motorola.

Rothschild was awarded a patent for a process used to make wide-band-gap semicon-

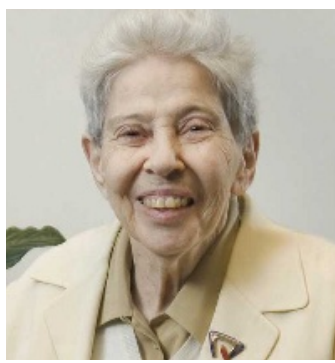

Gertrude Rothschild.
Dreier, a New York firm. "We believe that her patent covers the only viable commercial process," he says. The companies contacted by Nature declined to comment on the case.

Rothschild has taken on the electronics industry before. In 2005, she filed suit in federal court against two other companies: Toyoda Gosei of Japan and and Philips Lumiled. Both were settled out of court. But the trade commission complaint is further-reaching than the previous suits. If the commission finds in her favour then it may order the companies to cease and desist production, or ban the import, of equipment that contains the relevant technologies.

ductors in 1993. She had found an affordable way of making the semiconductors' resistivity low enough to make them commercially useful. It eventually allowed green, blue and ultraviolet LEDs and solid-state lasers to become common components in everything from mobile phones to the latest generation of DVD players.

Exactly how companies are producing the diodes is unknown because of trade secrets protection, but there is good reason to believe that Rothschild's process is being used, according to Albert Jacobs, the physicist's lawyer at
Rothschild says that she filed the complaint in part to raise awareness of women's role in science. "People don't pay too much attention unless there's a financial impact," she says.

This is not the first time that blue LEDs have been the subject of an intellectual-property dispute. In 2004, a Tokyo court awarded Nichia Corporation researcher Shuji Nakamura $¥ 20$ billion (US $\$ 180$ million) for his role in their development. This was later reduced to $¥ 840$ million after appeal.

Geoff Brumfiel

\section{The fraudster returns ...}

German academic Hans Werner Gottinger, whose penchant for inventing academic affiliations to promote his career was exposed by Nature last year, seems to be up to his old tricks.

This week, the German environmental economist was to run a 15-hour workshop for the Belgian organization Eurosis, at the University of Porto in Portugal. But the workshop was abandoned after the Ostendbased organization, which runs conferences and services promoting modelling and simulation, discovered that Gottinger was not the university professor he claimed to be.

Gottinger told Nature last August that he was in 'semi-retirement' (see Nature 448 , $632-633 ; 2007)$. But when he applied to run the Eurosis workshop just a few months later, he claimed to be a professor at the Technical University of Munich in Germany - specifying that he was director of the STRATEC Institute. The university says that it has never employed him and does not host such an institute. It is considering whether to take the matter beyond a formal request to desist.

Eurosis had accepted Gottinger's proposal, which was included in the organization's annual Future Business Technology conference, on 9-11 April. Philippe Geril, secretary-general of Eurosis, says that at the beginning of March, the University of Porto alerted the organization to potential problems. Gottinger withdrew from participation when Geril asked for more details of his affiliation. Gottinger did not respond to Nature's request for clarification.

Gottinger has held many real academic appointments at top universities and research institutes, but frequently used false claims on his $\mathrm{CV}$ to acquire them. He has also been accused of extensive plagiarism, including 13 confirmed cases.

Alison Abbott 